\title{
INTRODUCTION
}

\section{The True Wisdom of the Bill of Rights}

\author{
Philip B. Kurland
}

When The University of Chicago marked its centennial at the same time that the nation's Bill of Rights was reaching its bicentennial, the Law School held a two-day commemorative symposium and dinner featuring Justice John Paul Stevens, one of the current keepers of the sacred flame: mind, I did not say Vestal Virgin. This introduction to the papers delivered during the symposium is an act of supererogation. "If it be true that 'good wine needs no bush,' 'tis true that a good play needs no epilogue." And it is equally true that a good symposium needs no introduction. Just as the reader of Shakespeare's As You Like It can eschew the epilogue, so, too, can the reader of the symposium ignore the introduction, with which listeners to the symposium were not burdened. But having been given the opportunity to add my prejudices, cultivated over long decades, I offer a few banalities, in the hopes that some moderns will consider them truisms even if others may regard them as heresies.

As "every schoolboy knows," the American Constitution, like all Gaul, is made of three elements. The first creates the structure and authority of a republican form of government. The second provides a division of powers among the various parts of the national

† William R. Kenan, Jr., Distinguished Service Professor (Emeritus), New Collegiate Division, The University of Chicago, and The Law School. This introduction was prepared for The Bill of Rights in the Welfare State: A Bicentennial Symposium, held at The University of Chicago Law School on October 25-26, 1991.

'William Shakespeare, As You Like It (epilogue), in The Oxford Dictionary of Quotations 427 (Oxford, 3d ed 1979).

2 "How haughtily he cocks his nose, To tell what every schoolboy knows." Jonathan Swift, The Country Life, in id at 527. 
government-grossly labelled "separation of powers," which suggests monopolies but is really concerned with checks and balances, i.e., with shared powers rather than unification. And the third inhibits government power vis-à-vis the rights of individuals, rights existent and potential, patent and latent. One prime objective of each of the three parts was the liberty of the people.

It is error, although error more and more sought to be justified by academic theory, that the Constitution represents a single, cohesive theory to be found in Locke or Machiavelli or Rousseau or whomever the chosen swami may be. In fact, the Constitution was a series of pragmatic responses to a series of practical problems, as have been the Supreme Court decisions under it in the intervening centuries, however much within the perimeters of the Constitution's language.

If there had been an academic celebration of the centennial of the Bill of Rights, I expect that the "scholars" of a century ago would have been a good deal more circumspect than those of today. It was within the lifetimes of some professors not yet emeriti that Learned Hand observed the distinction between a Luther and an Erasmus:

You may take Martin Luther or Erasmus for your model, but you cannot play both roles at once; you may not carry a sword beneath a scholar's gown, lead flaming causes from a cloister, Luther cannot be domesticated in a university. You cannot raise a standard against oppression, or leap into the breach to relieve injustice, and still keep an open mind to every disconcerting fact, or an oper ear to the cold voice of doubt. I am satisfied that a scholar who tries to combine these parts sells his birthright for a mess of pottage; that when the final count is made, it will be found that the impairment of his powers far outweighs any possible contribution to the causes he has espoused. If he is fit to serve his calling at all, it is only because he has learned not to serve in any other, for his singleness of mind quickly evaporates in the fires of passions, however holy. ${ }^{3}$

You can, however, be true to scholarship and recognize that the Constitution is not a catalogue of rights and powers and duties. The "rights of Englishmen," some of which are stated in "the Bill of Rights," were not granted by the Constitution of 1789 , just as

${ }^{3}$ Learned Hand, On Receiving an Honorary Degree, in Irving Dilliard, ed, The Spirit of Liberty 138 (Phoenix, 3d ed 1960). 
the right to the writ of habeas corpus, often designated our most fundamental civil right, was not granted by the Constitution. True, some rights were specifically guaranteed by the Constitution. But from the beginning of our history, the rights guaranteed in terms by the Constitution have not been static. Some were not recognized at the "birth of the nation," in the language that we now know them, like the right to privacy and the right to freedom of religion. All were to be defined and redefined over time. The reality of our constitutional rights depended not on their identity over time, but on their continuity over time. The rule of today may be shown to have derived from the rule of yesterday, and the change is explainable by reason. Our future, like our present, is anchored in our past.

When today's constitutional rules are not dependent upon, or derived from, yesterday's, when they are not to be justified by reason but merely by fiat or personal prejudice, then the rule of law implicit in "due process" is gone. There are times when changes are made by fiat, thought to be demanded by circumstances, although not explicated by them. These instances must be few and far between, if we are to survive as a republic and a democracy. It is the Constitution that is the symbol of the uniqueness of this Nation, and the pith of that symbol-the Bill of Rights, however defined-ideally rejects the notions of arbitrary government. We pour into it, and therefore take out of it, an entire people's guide to what we need "to grow more civilized," a slow, painful, costly and always difficult choice.

In common parlance, the first Ten Amendments are "The Bill of Rights," the bicentennial of which we celebrated in December of 1991 on the two-hundredth anniversary of Virginia's ratification. But it was asserted by Hamilton in Federalist No. 84 that the entire Constitution was a Bill of Rights:

The truth is, after all the declamations we have heard, that the Constitution is itself, in every rational sense, and to every useful purpose, A BILL OF RIGHTS. The several bills of rights in Great Britain form its Constitution, and conversely the constitution of each State is its bill of rights. And the proposed Constitution, if adopted, will be the bill of rights of the Union. ${ }^{4}$

- Federalist 84 (Hamilton) in Clinton Rossiter, ed, The Federalist Papers 510, 515 (Mentor, 1961) (emphasis in original). 
In the end, the body of the Constitution did provide for trial by jury in criminal cases, did provide for trial in the vicinage, and did afford a definition of treason while limiting its sanction. Provision was made against ex post facto laws and bills of attainder; and, finally, provision was made that the mother writ of all civil liberty-habeas corpus-should "not be suspended, unless when in Cases of Rebellion or Invasion the public Safety may require it."

And so the third kind of constitutional provision afforded protection for the individual against the iniquities of government-particular iniquities, to be sure, that the Americans of 1789 and their English forebears had already suffered, and for most of which they had found some specific protection through the workings of the common law.

It was about a half-century ago that the principles of the American Bill of Rights enjoyed a renaissance-perhaps "naissance" would be more apt-in this nation. In Europe and Asia it had been demonstrated that tyrants could successfully manage societies in which a person lives without rights against government, where any individual's life, liberty, and property are destructable at the whim of officials. Only in the United States and England, and to a lesser extent in France, did "freedom" have substantial roots. And these roots, like the lesser ones planted by the "War to End All Wars," had been all but extirpated by deep economic depression, by a morbid fear that "socialism" was more of a threat to freedom than the serfdom of a medieval monarchy, by the paranoia labelled by Sinclair Lewis: "It Can't Happen Here." The United States was faced with the realization that its own form of racism was no more rational than Nazism, if usually less official.

The consequence of this realization was the growth of the Bill of Rights through the incorporation of their essence against the States. I suppose it must be acknowledged that this growth began in the Hughes Court, when Benjamin Cardozo wrote the decision in Palko $v$ Connecticut ${ }^{6}$ for the Court. When the Court deals with concepts such as liberty, it is giving itself extensive authority to oversee actions of the other two national branches of government and of the states toward individuals.

Cardozo's opinion in Palko was articulated, it will be noted, not in terms of literary construction, but in the larger vagary of "logical imperatives":

\footnotetext{
${ }^{5}$ US Const, Art I, § 9, cl 2.

${ }^{6} 302$ US 319 (1937).
} 
So it has come about that the domain of liberty withdrawn by the Fourteenth Amendment from encroachments by the states has been enlarged by latter-day judgments to include liberty of the mind as well as liberty of action. The extension indeed, became a logical imperative when once it was recognized, as long ago it was, that liberty is something more than exemption from physical restraint, and even in the field of substantive rights and duties the legislative judgment, if oppressive and arbitrary, may be overridden by the courts.

But this rejection of logic-chopping in favor of comprehension of purpose and function has long been recognized, as Holmes's familiar words in Gompers remind us:

[T] he provisions of the Constitution are not mathematical formulas having their essence in their form; they are organic living institutions transplanted from English soil. Their significance is vital not formal; it is to be gathered not simply by taking words and a dictionary, but by considering their origin and the line of their growth. ${ }^{8}$

To conclude, I suppose that what I want to say is really reducible to three observations:

First, the rights guaranteed by the Constitution in the Bill of Rights and in other places in the text require construction and do not involve merely the application of a fixed rule to a fixed fact. The significance of the facts and the function of the rule in the circumstances is dependent on the wisdom of the judgment of those charged with the adjudication. Our legal system is based on a different notion of reasoning than our sciences; it is inductive rather than deductive, which makes knowledge of the past so much more indispensable to the present and the future. This wisdom required of a Supreme Court Justice, alas, is not a subject communicable in the classroom, if communicable at all.

Second, the restraints of the Constitution are directed to the government and not to the individuals who are the governed. ${ }^{9}$ Thus the Constitution is a different order of law. True, individual freedom is more at risk from government behavior than from the

7 Id at 327.

- Gompers v United States, 233 US 604, 610 (1914).

- The exception is, of course, the Thirteenth Amendment, which applies to both individuals and the government: "Neither slavery nor involuntary servitude, except as a punishment for crime whereof the party shall have been duly convicted, shall exist within the United States, or any place subject to their jurisdiction." US Const, Amend XIII, $\$ 1$. 
behavior of other individuals, but this in part is dependent on government fulfilling its function of protecting individuals from impositions by other individuals. A person's life, liberty, and property are at risk from both private and public force, if in different degrees, and so the judicial task must encompass protections of a nonconstitutional order as well.

Third, the "liberty" that the Bill of Rights and cognate provisions in other parts of the Constitution protect is essentially the liberty to be different. It is here that the two centennial celebrations overlap, in their commitment to diversity, in their recognition that conformity and uniformity are denials of the essence of human personality. At the opening dinner of The University of Chicago's Centennial Celebration, Milton Friedman made the point thus:

"Why was one university so productive?"-asked economist Milton Friedman, AM, '33, one of the two U of C Nobelists who addressed the assembled diners. "In order to be a rich seedbed for new development, you do have to have a respect for diversity and a respect for innovation."10

Judge Learned Hand, himself born twenty years before the University, put it a little differently:

Because once you get people believing that there is an authoritative well of wisdom to which they can turn for absolutes, you have dried up the springs on which they must in the end draw even for the things of this world. As soon as we cease to pry about at random, we shall come to rely on accredited bodies of authoritative dogma; and as soon as we come to rely upon accredited bodies of authoritative dogma, not only are the days of our Liberty over, but we have lost the password that has hitherto opened to us the gates of success as well. ${ }^{11}$

There never has been more uniformity of interpretation of the language of the Bill of Rights than there has been a demonstrated singlemindedness of decision by the Justices of the Supreme Court. It will be too late for the Bill of Rights to fulfill its functions if the Court begins to speak with but one voice, for then it is not likely to be a judicial voice but a political one.

10 Mary Ruth Yoe, Pomp Meets Circumstance, U Chi Mag 26, 30 (Dec 1991).

"Learned Hand, Liberty, in Dilliard, ed, The Spirit of Liberty at 153 (cited in note 3). 